Published in final edited form as:

Integr Physiol Behav Sci. 2002 ; 37(4): 293-310.

\title{
Blockade of $\mathrm{GABA}_{\mathrm{A}}$ Receptors in the Interpositus Nucleus Modulates Expression of Conditioned Excitation but not Conditioned Inhibition of the Eyeblink Response
}

\author{
Brian C. Nolan, Daniel A. Nicholson, and John H. Freeman Jr. \\ Department of Psychology, University of lowa
}

\begin{abstract}
The cerebellum and related brainstem structures are essential for excitatory eyeblink conditioning. Recent evidence indicates that the cerebellar interpositus and lateral pontine nuclei may also play critical roles in conditioned inhibition (CI) of the eyeblink response. The current study examined the role of GABAergic inhibition of the interpositus nucleus in retention of CI. Male Long-Evans rats were implanted with a cannula positioned just above or in the anterior interpositus nucleus before training. The rats were trained with two different tones and a light as conditioned stimuli, and a periorbital shock as the unconditioned stimulus. CI training consisted of four phases: 1) excitatory conditioning ( $8 \mathrm{kHz}$ tone paired with shock); 2$)$ feature-negative discrimination (2 kHz tone paired with shock or $2 \mathrm{kHz}$ tone concurrent with light); 3) summation test ( $8 \mathrm{kHz}$ tone or $8 \mathrm{kHz}$ tone concurrent with light); and 4) retardation test (light paired with shock). After reaching a criterion level of performance on the feature-negative discrimination ( $40 \%$ discrimination), $0.5 \mu$ l picrotoxin $\left(\mathrm{a} \mathrm{GABA}_{\mathrm{A}}\right.$ receptor antagonist) was infused at one of four concentrations, each concentration infused during separate test sessions. Picrotoxin transiently impaired conditioned responses during trials with the excitatory stimulus (tone) in a dose-dependent manner, but did not significantly impact responding to the inhibitory compound stimulus (tone-light). The results suggest that expression of conditioned inhibition of the eyeblink conditioned response does not require GABAergic inhibition of neurons in the anterior interpositus nucleus.
\end{abstract}

\section{Introduction}

InHiBтoRY CondIIONING is a central component of theoretical models of associative learning (Pavlov, 1927; Pearce \& Hall, 1980; Rescorla, 1969; Rescorla \& Wagner, 1972), but its neural basis has not been fully elucidated. Conditioned inhibition is generally thought to be due to the development of an association between a conditioned stimulus (CS) and the omission of an unconditioned stimulus (US) or a no-US representation. Conditioned inhibition can be established using a discriminative training procedure that was developed by Pavlov (1927). In the Pavlov procedure (also known as feature-negative discrimination), two types of training trials are intermixed during discrimination training. The first type of training trial involves a single CS (e.g., a tone) paired with a US (e.g., a shock). The second type of training trial involves presentations of a compound stimulus that includes the first CS (e.g., a tone) and a second CS (e.g., a light). The compound stimulus is not followed by the US. The subject will develop conditioned responses (CRs) to the paired CS (i.e., tone) but not to the compound stimulus (i.e., tone-light). Summation and retardation tests have been used to show that the light becomes an inhibitory CS as a result of discrimination training (Marchant, Mis, \& Moore, 1972; Pavlov, 1927; Rescorla, 1969).

Address for Correspondence: John Freeman, Department of Psychology, University of Iowa, E-11 Seashore Hall, Iowa City, IA 52242. Electronic mail may be sent tojohn-freeman@uiowa.edu.. 
A series of studies investigated the neural mechanisms underlying conditioned inhibition of the fear-potentiated startle response in rats (Falls, Bakken, \& Heldt, 1997; Falls \& Davis, 1995; Gewirtz, Falls, \& Davis, 1997; Heldt, Falls, \& Coover, 2000; Waddell, Pistell, Heldt, \& Falls, 2000). Lesions of the medial prefrontal cortex, perirhinal cortex, or central nucleus of the amygdala had no effect on conditioned inhibition. However, lesions of the superior colliculus or medial geniculate nucleus (MGN) impair conditioned inhibition (Heldt et al., 2000; Waddell et al., 2000). Plasticity in the MGN and other parts of the auditory system has also been implicated in functional imaging studies of conditioned inhibition of fear (McIntosh \& Gonzalez-Lima, 1993; McIntosh \& Gonzalez-Lima, 1994; McIntosh \& Gonzalez-Lima, 1995). The findings of these studies suggest that inhibition may be initiated in the superior colliculus and MGN. The superior colliculus or MGN may produce behavioral inhibition of fear responses by inhibiting the neural systems that are necessary for conditioned fear during presentations of the conditioned inhibitor.

Eyeblink conditioning is an ideal paradigm for investigations of the neural mechanisms of conditioned inhibition because the neural circuitry for excitatory conditioning and expression of the CR has been identified (Kim \& Thompson, 1997; Lavond, Kim, \& Thompson, 1993; Thompson \& Krupa, 1994; Thompson, 2000; Yeo \& Hesslow, 1998). Knowledge of the neural circuitry underlying excitatory conditioning provides a framework for examining neuronal interactions that lead to inhibition of the CR. The necessary and sufficient circuitry for excitatory eyeblink conditioning exists within the brainstem and cerebellum. The CS pathway includes mossy fiber projections from the pontine nuclei to the cerebellum (Gould, Sears, \& Steinmetz, 1993; Lewis, LoTurco, \& Solomon, 1987; Solomon, Lewis, LoTurco, Steinmetz, \& Thompson, 1986; Steinmetz, Lavond, \& Thompson, 1985; Steinmetz, Rosen, Chapman, Lavond, \& Thompson, 1986; Steinmetz, Logan, Rosen, Thompson, Lavond, \& Thompson, 1987; Steinmetz, Lavond \& Thompson, 1989; Steinmetz, 1990; Tracy, Thompson, Krupa, \& Thompson, 1998). The US pathway includes climbing fiber projections from the inferior olive to the cerebellum (De Zeeuw, Van Alphen, Hawkins, \& Ruigrok, 1997; Gould et al., 1993; Mauk, Steinmetz \& Thompson, 1986; McCormick, Steinmetz, \& Thompson, 1985; Steinmetz et al., 1989; Yeo, Hardiman, \& Glickstein, 1986). In the cerebellum, information about the CS and US is integrated at two levels, the Purkinje cells in the cerebellar cortex and the neurons in the deep nuclei. Learning-related plasticity occurs in the cortex and the deep nuclei (Gould \& Steinmetz, 1996; Hardiman, Ramnani, \& Yeo, 1996; Kim \& Thompson, 1997; Lavond, et al., 1993; Mauk, 1997; Mauk \& Donegan, 1997; McCormick \& Thompson, 1984; Schreurs, Sanchez-Andres, \& Alkon, 1991; Schreurs, Tomsic, Gusev, \& Alkon, 1997; Schreurs, Gusev, Tomsic, Alkon, \& Shi, 1998; Schreurs, 2000; Steinmentz, Lavond, Ivkovich, Logan, \& Thompson, 1992; Thompson \& Krupa, 1994; Thompson, 2000; Yeo \& Hesslow, 1998). Several models argue that long-term depression (LTD) of parallel fiber inputs to Purkinje cells is a learning mechanism involved in excitatory conditioning (Albus, 1971; Gluck, Reifsnider, \& Thompson, 1990; Kim \& Thompson, 1997; Mauk, 1997; Mauk et al., 1998; Mauk \& Donegan, 1997; Thompson \& Krupa, 1994; Thompson, 2000; Yeo \& Hesslow, 1998). LTD has been demonstrated in vitro using parallel fiber stimulation followed by climbing fiber stimulation, a protocol which resembles delay conditioning (Chen \& Thompson, 1995; Freeman, Shi, \& Schreurs, 1998; Schreurs, Oh, \& Alkon, 1996). Moreover, several studies have shown changes in Purkinje cell simple spike activity that are consistent with the LTD hypothesis (Foy, Krupa, Tracy, \& Thompson, 1992; Gilbert \& Thach, 1977; Hesslow \& Ivarsson, 1994). The mechanisms underlying learning-specific plasticity in the cerebellar deep nuclei may involve changes in neuronal excitability or synaptic potentiation (Aizenman \& Linden, 2000; Racine, Wilson, Gingell, \& Sunderland, 1986). The output of the learning circuitry is the projection from the deep nuclei to the red nucleus, and from there to the relevant motor nuclei (Chapman, Steinmetz, Sears, \& Thompson, 1990; Clark \& Lavond, 1993; Desmond, Rosenfield, \& Moore, 1983; Krupa \& Thompson, 1995; Krupa, Thompson, \& 
Thompson, 1993; Krupa, Weng, \& Thompson, 1996; McCormick, Guyer, \& Thompson, 1982; Rosenfield \& Moore, 1983).

The essential neural circuitry underlying eyeblink conditioned inhibition is not clearly understood. However, several studies have identified structures that are not involved in conditioned inhibition. Lesions of the hippocampus or removal of the neocortex do not disrupt conditioned inhibition acquisition or retention (Moore, Yeo, Oakley, Russell, 1980; Solomon, 1977; Yeo, Hardiman, Moore, \& Russell, 1983). Mis (1977) found that stimulation of the nucleus of Darkschewitsch, interstitial nucleus of Cajal, or anterior red nucleus inhibited CR production, and lesions of these areas prevented acquisition of conditioned inhibition. This work was extended by Berthier and Moore (1980), who demonstrated that similar mesencephalic lesions also disrupted retention of conditioned inhibition. However, Blazis and Moore (1991) demonstrated that mesencephalic lesions only transiently disrupted conditioned inhibition. With further training, the rabbits eventually recovered conditioned inhibition performance. Mesencephalic structures may play a role in conditioned inhibition but the precise nature of any such role requires further investigation.

Recent evidence indicates that the lateral pontine and interpositus nuclei may be involved in conditioned inhibition (Freeman \& Nicholson, 1999; Nicholson \& Freeman, 2002). A decrease in neuronal activity during inhibitory trials relative to the activity during excitatory trials was observed in the lateral pontine and interpositus nuclei. One possible explanation for this "neuronal discrimination" is that Purkinje cells were more strongly inhibiting the interpositus nucleus during presentations of the inhibitory $\mathrm{CS}$ as a result of training. The increased inhibition in the interpositus nucleus would inhibit production of the CR during the inhibitory CS. Moreover, a previous study showed that lesions of the cerebellar cortex impaired acquisition of conditioned inhibition in rabbits (Logan, 1991). An increase in Purkinje cell inhibition would also decrease the excitatory feedback projections from the interpositus nucleus to the pontine nuclei and could produce neuronal discrimination in the CS pathway (Freeman \& Nicholson, 1999).

The mechanism underlying the hypothesized increased Purkinje cell inhibition during conditioned inhibition could be long-term potentiation (LTP) of the parallel fiber inputs to Purkinje cells (Choi, 1999; Freeman \& Nicholson, 1999; Mauk \& Donegan, 1997; Moore \& Choi, 1997). Paired stimulation of parallel and climbing fibers induces LTD (Chen \& Thompson, 1995; Schreurs, Oh, \& Alkon, 1996; Freeman, Shi, \& Schreurs, 1998), but parallel fiber stimulation without climbing fiber stimulation can induce LTP (Sakurai, 1987; Salin, Malenka, \& Nicoll, 1996). It is possible that the parallel fiber-alone stimulation that presumably occurs during the non-reinforced compound stimulus in conditioned inhibition training induces LTP in Purkinje cells. LTP would amplify Purkinje cell inhibition of the deep nuclei when the inhibitory stimulus was presented and in turn inhibit the production CRs (Freeman \& Nicholson, 1999; Mauk \& Donegan, 1997; Moore \& Choi, 1997). As mentioned above, several models argue that excitatory conditioning involves LTD of parallel fiber inputs to Purkinje cells (e.g., Thompson \& Krupa, 1994). Purkinje cells may therefore be involved in both conditioned excitation and conditioned inhibition through different synaptic mechanisms.

The current experiment was designed to test the hypothesis that the Purkinje cell GABAergic projection to the interpositus nucleus is the source of neural inhibition that is necessary for the expression of conditioned inhibition. The $\mathrm{GABA}_{\mathrm{A}}$ receptor antagonist, picrotoxin, was infused into the anterior interpositus nucleus to block the Purkinje cell inhibitory synapses (and any other synapses with $\mathrm{GABA}_{\mathrm{A}}$ receptors) in rats that had acquired conditioned inhibition of the eyeblink response during training with a feature-negative discrimination procedure. The feature-negative discrimination procedure involved presentations of a tone CS paired with a periorbital shock US $(\mathrm{T}+)$ during half of the trials, and presentations of the tone CS 
simultaneously with a light CS without the US (TL-) during the other half of the trials. Rats trained with this procedure initially produce eyeblink CRs during both types of trials and decrease responding to the TL- compound stimulus as training progresses (Freeman \& Nicholson, 1999; Nicholson \& Freeman, 2002). In the current experiment, picrotoxin was infused during over-training sessions with the feature-negative discrimination procedure. Blockade of conditioned inhibition can be assessed by examining whether the rats continue to suppress responding during trials in which the $\mathrm{TL}-$ compound stimulus is presented. If the inhibitory mechanism is blocked by picrotoxin, the rats would respond to the tone CS during trials with the TL-compound stimulus, as they do early in training.

Previous studies demonstrated that picrotoxin produces a transient dose-dependent suppression of conditioned excitation (Bao, Chen, Kim, \& Thompson, 2002; Mamounas, Thompson, \& Madden, 1987). The nearly complete but transient suppression of CRs at higher doses of picrotoxin temporarily precludes the analysis of its effects on discriminative responding. Therefore, behavioral comparisons must be made at a time during the testing session when responding to the excitatory stimulus is only partially impaired with lower doses or when responding has started to recover from suppression at higher doses (e.g., when CRs are being produced on $50 \%$ of the trials with the excitatory CS). The partial impairment of CRs during excitatory trials can be thought of as an indicator that the picrotoxin is working. If picrotoxin affects conditioned inhibition, there should be at least a partial increase in responding to the $\mathrm{TL}-$ compound stimulus when responding to the excitatory stimulus is partially suppressed (i.e., when picrotoxin is still working). Moreover, if cerebellar cortical inhibition of the interpositus nucleus is the primary mechanism underlying the expression of conditioned inhibition, the percentage of CRs during trials with the TL- compound stimulus should be the same as the percentage of CRs during the T+ trials. In contrast, if picrotoxin selectively affects conditioned excitation, there should be no increase in responding during trials with the TLcompound stimulus when picro-toxin is still effective at partially suppressing CRs during $\mathrm{T}+$ trials.

\section{Method \\ Subjects}

Subjects were 12 adult male Long-Evans rats $(250-350 \mathrm{~g})$. The rats were housed in an animal colony room in the Spence Laboratory building at the University of Iowa. Animals were allowed $a d$ lib food and water and maintained on a 12-hour light-dark cycle.

\section{Surgery}

Surgery was performed one week prior to training. Each rat was anesthetized with an i.p. injection of sodium pentobarbital $(60 \mathrm{mg} / \mathrm{kg})$ and atropine sulfate $(0.67 \mathrm{mg} / \mathrm{kg})$. Upon onset of anesthesia, the rat was placed in a stereotaxic apparatus. A $23 \mathrm{~g}$ guide cannula was lowered into the cerebellum above the interpositus nucleus (from bregma, $\mathrm{AP}=-11.7 \mathrm{~mm}, \mathrm{ML}=+2.3 \mathrm{~mm}$, DV -4.0 to $-4.5 \mathrm{~mm}$ ). A tungsten electrode was placed inside the cannula so that the electrode extended $1.5 \mathrm{~mm}$ beyond the end of the guide cannula. Neuronal activity was monitored to guide cannula placement. The cannula was then cemented in place with dental acrylic. Once the acrylic had hardened around the cannula, the tungsten electrode was removed and replaced by a $30 \mathrm{~g}$ dummy cannula, which extended $1.0 \mathrm{~mm}$ beyond the guide cannula (the infusion cannula was also $30 \mathrm{~g}$ and extended $1.0 \mathrm{~mm}$ beyond the guide cannula). Differential EMG electrodes were then implanted in the left upper eyelid muscle (orbicularis oculi) with a ground wire attached to a skull screw. The two EMG wires and the ground wire were attached to a small plastic connector with 3 gold amphenol pins for cable connection. A bipolar stimulating electrode (Plastics One, Roanoke, VA) was implanted subdermally caudal to the left eye. The bipolar electrode was attached to a plastic connector for cable connection. All components 
were then cemented in place with dental acrylic and sutures were made as necessary. The rats were monitored after surgery until they recovered from the anesthetic and then were returned to the colony room. The procedures used in this study were approved by the Animal Care and Use Committee at the University of Iowa.

\section{Training Apparatus}

Conditioning apparatus consisted of four small-animal sound attenuation chambers (BRS/

LVE, Laurel, MD). Within each sound attenuation chamber was a small-animal operant chamber (BRS/LVE, Laurel, MD) which was fitted with two speakers that independently produce tones up to $120 \mathrm{~dB}$ and frequencies of 1000 to $9000 \mathrm{~Hz}$, and a small light. The sound attenuation chambers also contained a mounted fan to provide background white noise (about $65 \mathrm{~dB})$.

The plugs on the rat's headstage were connected to lightweight cables for the EMG and shock electrodes. A medium-weight metal coil covered part of the cables to prevent the rats from chewing through the cables. The cables were connected to peripheral equipment for recording EMG activity and delivering stimuli. The EMG signal was recorded differentially, filtered (500-5000 Hz), amplified, integrated, and then input to a computer where it was recorded and displayed by custom software. The same software controlled the delivery of the stimuli (light, tone, or shock). The shock stimulus (2-3 mA, DC) was produced by a stimulus isolator (model 365A World Precision Instruments, Sarasota, FL).

\section{Training Procedure}

All training sessions were performed once daily and consisted of 100 trials (except where noted below). The internal chamber lights were off during training and testing. The duration of all conditioned stimuli (CSs) was $400 \mathrm{~ms}$. The unconditioned stimulus (US) was a shock delivered at $2-3 \mathrm{~mA}$ for $25 \mathrm{~ms}$. The average intertrial interval was $30 \mathrm{~s}$ (ranging from 20 to $40 \mathrm{~s}$ ).

Conditioned inhibition (CI) training consisted of five phases (Table 1): acquisition, featurenegative discrimination, drug infusion/retention test, summation test, and retardation test. During Phase 1 (acquisition), the rats received paired trials of an $8 \mathrm{kHz}$ tone and a shock US. Upon reaching a criterion of $80 \%$ CRs on Phase 1, the rats began Phase 2 (feature-negative discrimination) training, which consisted of 50 trials of a $2 \mathrm{kHz}$ tone paired with the US (T+) and 50 trials of the $2 \mathrm{kHz}$ tone concurrent with a light and no US (TL-) in each session. Upon reaching a criterion of at least $40 \%$ discrimination between $\mathrm{T}+$ and $\mathrm{TL}-$ trials, the rats began Phase 3, which was exactly the same as Phase 2 except that picrotoxin or vehicle was infused prior to each of four sessions. During Phase 3, $0.5 \mu \mathrm{l}$ of four different drug doses was administered on separate training sessions using artificial cerebro-spinal fluid (ACSF) as the vehicle: ACSF, $1.0 \mathrm{mM}$ picrotoxin, $2.0 \mathrm{mM}$ picrotoxin, and $4.0 \mathrm{mM}$ picrotoxin. Afterwards, an additional training session with no drug or vehicle was performed to ensure that the conditioned responses recovered completely. The final two phases, summation and retardation, were standard tests used to determine that the light had become a conditioned inhibitor (Rescorla 1969). The summation test consisted of 40 trials of the $8 \mathrm{kHz}$ tone (used in Phase 1) and 40 trials of the $8 \mathrm{kHz}$ tone concurrent with the light. If the light is an inhibitory stimulus, there should be less responding during the compound stimulus. The final phase, the retardation test, consisted of two 100 trial sessions of the light paired with the shock US. This procedure shows that the light is a conditioned inhibitor by demonstrating that it is more difficult to establish the light as an excitatory stimulus after conditioned inhibition training.

\section{Drug Infusion Procedure}

ACSF solution (the vehicle) was prepared daily. The picrotoxin solution was also prepared daily at $1.0 \mathrm{mM}, 2.0 \mathrm{mM}$, or $4.0 \mathrm{mM}$. Prior to the test sessions, the dummy cannula was removed 
from the guide cannula and was replaced with an infusion cannula (30g). The infusion cannula was connected to polyethylene tubing (PE 10, 110 to $120 \mathrm{~cm}$ ), which was connected to a 10 $\mu \mathrm{l}$ gas tight Hamilton Syringe (Reno, NE). The syringe was placed in an infusion pump (Harvard Apparatus, Holliston, MA) and $0.5 \mu \mathrm{l}$ of drug was infused at a rate of $60 \mu \mathrm{l} / \mathrm{hr}$. The infusion cannula was allowed to remain in place for 5 minutes before replacing it with the dummy cannula. The rats were then placed in the training chamber to begin the session. The time from the beginning of the drug infusion until the first trial was 10 to 15 minutes.

\section{Histology}

After completion of training, the rats were killed with a lethal injection of sodium pentobarbital $(90 \mathrm{mg} / \mathrm{kg})$ and transcardially perfused with physiological saline followed by $3 \%$

formaldehyde. The brains were carefully removed and placed in $10 \%$ sucrose dissolved in phosphate buffered saline and allowed to soak for at least 24 hours. Using a microtome, 50 $\mu \mathrm{m}$ horizontal sections were prepared, stained with cresyl violet, and inspected under a light microscope to determine the precise location of the cannula.

\section{Results \\ Cannula Placement}

Histological analysis revealed the location of the cannula tips (Figure 1). Among the rats that successfully completed the training, 6 were identified as "hits" and 6 were identified as "misses." A hit was defined as a cannula placement within either the anterior interpositus or dentate nuclei. Four of the hits were in the anterodorsal interpositus nucleus, one hit was in the ventral anterior interpositus nucleus, and one hit was in the dentate nucleus. The misses did not fall within the interpositus or dentate nuclei. Several of the misses were within $1 \mathrm{~mm}$ of the anterior interpositus nucleus. Figure 1 shows the location of the cannula tips for all 12 animals.

\section{Behavioral Data}

Prior to drug administration all rats had successfully acquired the feature-negative discrimination (see methods). To measure the effect due to picrotoxin, performance during the ACSF session (see methods) was used as the baseline. Performance with or without ACSF did not differ (data not shown). Figure 2 shows the average percentage of conditioned responses (CRs) for rats classified as hits. The percentage of CRs for both tone-shock $(\mathrm{T}+$ ) and tone-light $(\mathrm{TL}-)$ trials are displayed for each drug concentration used. There was a dose-dependent reduction in CR percentage during the $\mathrm{T}+$ trials and no significant effect on the CR percentage during the $\mathrm{TL}-$ trials. The dose-dependent effect of picrotoxin on excitatory conditioning is consistent with a previous report (Mamounas, Thompson, \& Madden, 1987). A repeated measures analysis of variance (ANOVA) demonstrated an interaction involving the stimulustype (T+ vs. TL-), dose (ACSF vs. $1.0 \mathrm{mM}$ picrotoxin vs. $2.0 \mathrm{mM}$ picrotoxin vs. $4.0 \mathrm{mM}$ picrotoxin), and block (20 trials per block) factors, $\mathrm{F}(12,60)=2.66, \mathrm{p}<0.01$. Post hoc tests (Tukey's HSD) determined that the percentage of CRs during the first 2 blocks for the $2.0 \mathrm{mM}$ picrotoxin and the first 3 blocks for the $4.0 \mathrm{mM}$ picrotoxin were significantly lower than during the ACSF session for the $\mathrm{T}+$ trials (all comparisons, $\mathrm{p}<0.05$ ). Furthermore, the drug effect seemed to wear off during the course of the session such that the CR was nearly or fully recovered by the end of the session. Post hoc tests showed that the percentage CRs in the last 2 blocks of trials did not differ significantly for any of the doses of picrotoxin (all comparisons, $\mathrm{p}<0.05)$. There were no significant differences in CR percentage between testing sessions during $\mathrm{TL}-$ trials.

Figure 3 shows the average percentage of $\mathrm{CR}$ for rats classified as misses. Picrotoxin had no significant effect on the performance of these rats. A repeated measures ANOVA demonstrated 
a main effect of the stimulus-type factor, $F(12,60)=0.28, p<0.001$. This effect was due to a higher percentage of CRs during $\mathrm{T}+$ trials relative to $\mathrm{TL}-$ trials.

The amplitude of both CRs and URs were examined for both hit and miss groups (Figures 4 and 5). Figure 4 shows the CR amplitudes across doses. The trend seen in the CR amplitude is similar to that seen in the CR percentage. The hit group demonstrated a dose-dependent reduction of $\mathrm{CR}$ amplitude on $\mathrm{T}+$ trials and no effect on $\mathrm{TL}-$ trials. A repeated measures ANOVA demonstrated an interaction of stimulus-type and dose factors for the hit group, $\mathrm{F}$ ( 3 , $15)=3.46, \mathrm{p}<0.05$. Post hoc tests demonstrated that only the amplitude for the $4.0 \mathrm{mM}$ session was significantly different from the ACSF session during T+ trials. There was no effect for either trial type or dose in the miss group. A main effect of the stimulus-type factor, $F(1,5)=$ $35.08, \mathrm{p}<0.01$, was detected. This effect was due to a greater CR amplitude on $\mathrm{T}+$ trials relative to $\mathrm{TL}-$ trials. There were no significant effects for either hit or miss groups on UR amplitude (Figure 5).

Summation and retardation tests were conducted for both hit and miss groups. There were no significant differences between hit and miss groups for the percentage or amplitude of CRs during the summation test. Figure 6 shows the results of the summation test. A t-test found that the difference in $\mathrm{CR}$ percentage during tone presentations was significantly higher than the $\mathrm{CR}$ percentage during tone-light compound presentations, $\mathrm{t}(12)=3.05, \mathrm{p}<0.01$. Figure 6 also shows the results of the retardation test. As seen in the results of the summation test, there were no significant differences between hit and miss groups for the percentage or amplitude of CRs during the retardation test. For the retardation test results, the performance of the CI experimental rats was compared to the performance of rats run on a behavioral control paradigm $(n=6)$, which involved replacing the $T L-$ trials during the feature-negative discrimination phase with unpaired presentations of the tone and light (Nicholson and Freeman, unpublished). The results indicated that the $\mathrm{CI}$ rats were impaired when compared to the behavioral controls $(\mathrm{t}(11)=2.84, \mathrm{p}<0.05)$. The summation and retardation tests provide evidence that the featurenegative discrimination procedure established conditioned inhibition.

\section{Discussion}

There was a dose-dependent reduction in CR percentage and amplitude during trials with the excitatory CS following picrotoxin infusion in the anterior interpositus or dentate nuclei. No changes in CR percentage or amplitude due to picrotoxin infusion were observed during trials with the inhibitory CS. The rats with missed cannulae (even within $1.0 \mathrm{~mm}$ of the interpositus nucleus) failed to show any effect due to picrotoxin infusion.

The reduction in CR percentage observed during excitatory trials with picrotoxin generally replicated a previous study, which showed a dose-dependent reduction of CRs during excitatory conditioning in rabbits (Mamounas et al., 1987). The current study was designed to examine of the effects of picrotoxin on CRs during retention of conditioned inhibition. If Purkinje cells are a critical source of neural and behavioral inhibition during conditioned inhibition, infusion of a $\mathrm{GABA}_{\mathrm{A}}$ receptor antagonist into the interpositus nucleus should disrupt performance during inhibitory trials (i.e., increase $\mathrm{CR}$ percentage). The predicted outcome of this experiment was that the percentage of CRs during trials with the inhibitory CS would increase as the percentage of CRs during the excitatory CS recovered from picrotoxininduced suppression. No effect of picrotoxin was observed during the inhibitory trials at any of the doses tested or during any part of the test session. The failure to modulate the behavioral inhibition during testing suggests that Purkinje cell inhibition of the interpositus nucleus is not critical for the expression of conditioned inhibition. However, it is possible that Purkinje cell inhibition is involved in the acquisition of conditioned inhibition (Logan, 1991), but not in its retention or expression. 
The dose-dependent transient suppression of CRs during trials with the excitatory CS is somewhat surprising because several models of eyeblink conditioning posit that CRs are generated as Purkinje cell inhibition is reduced by long-term depression of parallel fiber synapses (Albus, 1971; Gluck, Reifsnider, \& Thompson, 1990; Mauk \& Donegan, 1997; Mauk, Garcia, Medina, \& Steele, 1998; Medina \& Mauk, 2000; Nores, Medina, Steele, \& Mauk, 2000). Why would removing GABAergic inhibition impair the production of CRs? One possibility is that $\mathrm{CR}$ production normally requires Purkinje cell inhibition to produce a rebound depolarization or to specifically shape CR topography (Aizenman \& Linden, 1999; Gould \& Steinmetz, 1996; Hesslow, 1994; Katz, Tracy, \& Steinmetz, 2001; Medina, Garcia, Nores, Taylor, \& Mauk, 2000; Schreurs, 2000; Schreurs et al., 1998). Blocking GABAergic synaptic transmission would block the inhibition that is necessary for producing the rebound response in the interpositus nucleus (Aizenman \& Linden, 1999). It is also possible that the higher doses of picrotoxin produced non-specific effects on interpositus neurons that temporarily inhibited their output. Non-specific effects of picrotoxin were observed in a study that used an isolated invertebrate axon preparation to demonstrate that high bath concentrations of picrotoxin produce inactivation of action potentials (Freeman, 1973). It is unlikely that the local picrotoxin concentration in vivo ever approached levels that were equivalent to the bath application in the Freeman (1973) study. However, it is still possible that a non-specific pharmacological effect reduced the percentage of CRs during picrotoxin infusions in the current experiment. No matter what mechanism produced the reduction in CRs during excitatory trials, the important point for the current study is that picrotoxin administration did not reduce behavioral inhibition.

One of the underlying assumptions of this study was that the neural mechanisms of inhibitory conditioning occur within the cerebellar-brainstem circuitry that is necessary and sufficient for excitatory conditioning. If Purkinje cells are not the source of neural inhibition underlying conditioned inhibition, then there may be a source of inhibition within the eyeblink circuitry that does not include GABAergic synapses in the interpositus nucleus. For instance, it is possible that long-term depression of mossy fiber connections to the interpositus nucleus is induced during conditioned inhibition. Another possibility is that inhibition is occurring at the level of the red nucleus. Recent experiments found that neuronal activity in the red nucleus exhibited a stronger correlation with conditioned inhibition in rabbits than neuronal activity in the interpositus nucleus (Britton, Brown, \& Steinmetz, 2000; Brown, Britton, \& Steinmetz, 2000). If conditioned inhibition is mediated by synaptic plasticity in the red nucleus, inactivation of the red nucleus should selectively block the acquisition and expression of conditioned inhibition. There are also GABAergic feedback connections from the cerebellum to the pontine nuclei that could inhibit CS inputs to the cerebellum (Border, Kosinski, Azizi, \& Mihailoff, 1986; Border \& Mihailoff, 1985). At present, there are still several plausible mechanisms for producing inhibition of the eyeblink response within the circuitry that is essential for excitatory conditioning.

It is also possible that neural systems that are not essential for excitatory conditioning affect the CS inputs to the cerebellum or the mechanisms of CR expression during conditioned inhibition. The superior colliculus has been implicated in conditioned inhibition of fearpotentiated startle (Waddell et al., 2000) and has synaptic connections with the pon-tine nuclei (Wells, Hardiman, \& Yeo, 1989). The lateral geniculate nuclei also project to the pontine nuclei (Ribak \& Peters, 1975; Wells et al., 1989). Extra-eyeblink-circuit structures may therefore modulate activity of neurons that provide the CS inputs to the cerebellum. There may also be neural systems that inhibit neurons in the parts of the eyeblink circuitry that are necessary for the expression of CRs. The Darkschewitsch nucleus and interstitial nucleus of Cajal have been implicated in conditioned inhibition (Mis, 1977) and project to the facial nucleus (Fanardjian \& Manvelyan, 1987; Holstege, Tan, van Ham, \& Bos, 1984; Isokawa-Akesson \& Komisaruk, 1987; Takada, Itoh, Yasui, Mitani, Nomura, \& Mizuno, 1984), which is necessary for 
producing the eyeblink response. The superior colliculus also projects to the facial nucleus (Isokawa-Akesson \& Komisaruk, 1987). The superior colliculus, Darkschewitsch nucleus, and interstitial nucleus of Cajal are neural systems that could inhibit the facial motor nucleus and therefore inhibit the eyeblink response. Current experiments are directed toward examining the roles of the superior colliculus and Darkschewitsch nucleus in conditioned inhibition.

The neural mechanisms of conditioned inhibition are just beginning to be elucidated for both eyeblink conditioning and fear potentiated startle. Although eyeblink and fear CRs are generated by distinct neural circuits, the mechanisms underlying inhibition of these CRs may involve the same neural systems (i.e., the superior colliculus or sensory thalamus).

Alternatively, conditioned inhibition of eyeblink and fear CRs could be mediated within the circuitry that is necessary for excitatory conditioning but induced by different synaptic mechanisms. Further studies are also necessary to determine whether conditioned inhibition of the eyeblink response depends on a neural inhibitory mechanism or is due to a lack of excitation during testing.

\section{Acknowledgements}

This work was supported by National Institute of Neurological Disorders and Stroke Grant NS38890. We thank Terry Beltz for advice regarding cannula fabrication and implantation, and Dr. Michael Mauk for advice regarding the drug infusion method and behavioral testing.

\section{References}

Aizenman CD, Linden DJ. Regulation of the rebound depolarization and spontaneous firing patterns of the deep nuclear neurons in slices of rat cerebellum. Journal of Neurophysiology 1999;82:1697-1709. [PubMed: 10515960]

Aizenman CD, Linden DJ. Rapid, synaptically driven increases in the intrinsic excitability of cerebellar deep nuclear neurons. Nature Neuroscience 2000;3:109-111.

Albus JS. A theory of cerebellar function. Mathematical Biosciences 1971;10:25-61.

Bao S, Chen L, Kim JJ, Thompson RF. Cerebellar cortical inhibition and classical eyeblink conditioning. Proceedings of the National Academy of Sciences 2002;99:1592-1597.

Berthier NE, Moore JW. Disrupted conditioned inhibition of the rabbit nictitating membrane response following mesencephalic lesions. Physiology and Behavior 1980;25:667-673. [PubMed: 7443828]

Blazis DEJ, Moore JW. Conditioned inhibition of the nictitating membrane response in rabbits following hypothalamic and mesencephalic lesions. Behavioral Brain Research 1991;46:71-81.

Border BG, Kosinski RJ, Azizi SA, Mihailoff GA. Certain basilar pontine afferent systems are GABAergic: combined HRP and immunocytochemical studies in the rat. Brain Research Bulletin 1986;17:169-179. [PubMed: 2429739]

Border BG, Mihailoff GA. GAD-immunoreactive neural elements in the basilar pontine nuclei and nucleus reticularis tegmenti pontis of the rat. I. Light microscopic studies. Experimental Brain Research 1985;59:600-614.

Britton, G., Brown, T. C., \& Steinmetz, J. E. (2000). Single-unit activity from interpositus nucleus during conditioned inhibition of the eyeblink response. Society for Neuroscience Abstracts.

Brown, T. C., Britton, G., \& Steinmetz, J. E. (2000). The role of red nucleus in conditioned inhibition of the rabbit eyeblink response. Society for Neuroscience Abstracts.

Chapman PF, Steinmetz JE, Sears LL, Thompson RF. Effects of lidocaine injection in the interpositus nucleus and the red nucleus on conditioned behavioral and neuronal responses. Brain Research 1990;537:149-156. [PubMed: 2085770]

Chen C, Thompson RF. Temporal specificity of long-term depression in parallel fiber-Purkinje synapses in rat cerebellar slice. Learning \& Memory 1995;2:185-98. [PubMed: 10467575]

Choi, J. S. (1999). Classical eyeblink conditioning with mixed interstimulus intervals: temporal integration of response topography and neuronal correlates. Doctoral Dissertation, University of Massachusetts. 
Clark RE, Lavond DG. Reversible lesions of the red nucleus during acquisition and retention of a classically conditioned behavior in rabbits. Behavioral Neuroscience 1993;107:264-270. [PubMed: 8484892]

Desmond JE, Rosenfield ME, Moore JW. An HRP study of the brainstem afferents to the accessory abducens region and dorsolateral pons in rabbit: Implications for the study of the conditioned nictitating membrane response. Brain Research Bulletin 1983;10:747-763. [PubMed: 6616268]

De Zeeuw CI, Van Alphen AM, Hawkins RK, Ruigrok TJ. Climbing fiber collaterals contact neurons in the cerebellar nuclei that provide a GABAergic feedback to the inferior olive. Neuroscience 1997;80:981-986. [PubMed: 9284054]

Falls WA, Bakken KT, Heldt SC. Lesions of the perirhinal cortex interfere with conditioned excitation but not with conditioned inhibition of fear. Behavioral Neuroscience 1997;111:476-486. [PubMed: 9189262]

Falls WA, Davis M. Lesions of the central nucleus of the amygdala block conditioned excitation, but not conditioned inhibition of fear as measured with the fear-potentiated startle effect. Behavioral Neuroscience 1995;109:379-387. [PubMed: 7662148]

Fanardjian VV, Manvelyan LR. Mechanisms regulating the activity of facial nucleus motoneurons-IV. Influences from the brainstem structures. Neuroscience 1987;20:845-853. [PubMed: 3601066]

Foy MR, Krupa DJ, Tracy J, Thompson RF. Analysis of single unit recordings from cerebellar cortex of classically conditioned rabbits. Society for Neuroscience Abstracts 1992;18:1215.

Freeman AR. Electrophysiological analysis of the actions of strychnine, bicuculline and picrotoxin on the axonal membrane. Journal of Neurobiology 1973;4:567-582. [PubMed: 4149605]

Freeman JH Jr, Nicholson DA. Neuronal activity in the cerebellar interpositus and lateral pontine nuclei during inhibitory classical conditioning of the eyeblink response. Brain Research 1999;833:225-233. [PubMed: 10375698]

Freeman JH Jr, Shi T, Schreurs BG. Pairing-specific long-term depression prevented by blockade of PKC or intracellular $\mathrm{CA}^{2+}$ NeuroReport 1998;9:2237-2241. [PubMed: 9694206]

Gewirtz JC, Falls WA, Davis M. Normal conditioned inhibition and extinction of freezing and fearpotentiated startle following electrolytic lesions of medial prefrontal cortex in rats. Behavioral Neuroscience 1997;111:712-726. [PubMed: 9267649]

Gilbert PF, Thach WT. Purkinje cell activity during motor learning. Brain Research 1977;128:309-328. [PubMed: 194656]

Gould TJ, Steinmetz JE. Changes in rabbit cerebellar cortical and interpositus nucleus activity during acquisition, extinction, and backward classical eyelid conditioning. Neurobiology of Learning and Memory 1996;65:17-34. [PubMed: 8673404]

Gould TJ, Sears LL, Steinmetz JE. Possible CS and US pathways for rabbit classical eyelid conditioning: Electrophysiological evidence for projections from the pontine nuclei and inferior olive to cerebellar cortex and nuclei. Behavioral and Neural Biology 1993;60:172-185. [PubMed: 8117241]

Gluck, M. A., Reifsnider, E. S., \& Thompson, R. F. (1990). Adaptive signal processing and the cerebellum: Models of classical conditioning and VOR adaptation. In M. A. Gluck \& D. E. Rumelhart (Eds.), Neuroscience and connectionist theory (pp. 131-185). Hillsdale, NJ: Lawrence Erlbaum Associates, Inc.

Hardiman MJ, Ramnani N, Yeo CH. Reversible inactivations of the cerebellum with muscimol prevent the acquisition and extinction of conditioned nictitating membrane responses in the rabbit. Experimental Brain Research 1996;110:235-247.

Heldt, S. A., Falls, W. A., \& Coover, G. D. (2000). NMDA lesions of the auditory thalamus attenuate expression of conditioned inhibition of fear-potentiated startle. Society for Neuroscience Abstracts.

Hesslow G. Correspondence between climbing fibre input and motor output in eyeblink-related areas in cat cerebellar cortex. Journal of Physiology 1994;476:229-244. [PubMed: 8046640]

Hesslow G, Ivarsson M. Suppression of cerebellar Purkinje cells during conditioned responses in ferrets. NeuroReport 1994;5:649-652. [PubMed: 8025262]

Holstege G, Tan J, van Ham J, Bos A. Mesencephalic projections to the facial nucleus in the cat. An autoradiographical tracing study. Brain Research 1984;311:7-22. [PubMed: 6207897] 
Isokawa-Akesson M, Komisaruk BR. Difference in projections to the lateral and medial facial nucleus: anatomically separate pathways for rhythmical vibrissa movement in rats. Experimental Brain Research 1987;65:385-398.

Katz DB, Tracy JA, Steinmetz JE. Rabbit classical eyeblink conditioning is altered by brief cerebellar cortical stimulation. Physiology and Behavior 2001;72:499-510. [PubMed: 11282133]

Kim JJ, Thompson RF. Cerebellar circuits and synaptic mechanisms involved in classical eyeblink conditioning. Trends in Neuroscience 1997;20:177-181.

Krupa DJ, Thompson RF. Inactivation of the superior cerebellar peduncle blocks expression but not acquisition of the rabbit's classically conditioned eyeblink response. Proceedings of the National Academy of Science USA 1995;92:5097-5101.

Krupa DJ, Thompson JK, Thompson RF. Localization of a memory trace in the mammalian brain. Science 1993;260:989-991. [PubMed: 8493536]

Krupa DJ, Weng J, Thompson RF. Inactivation of brainstem motor nuclei blocks expression but not acquisition of the rabbit's classically conditioned eyeblink response. Behavioral Neuroscience 1996;110:219-227. [PubMed: 8731049]

Lavond DG, Kim JJ, Thompson RF. Mammalian brain substrates of aversive classical conditioning. Annual Review of Psychology 1993;44:317-342.

Lewis JL, LoTurco JJ, Solomon PR. Lesions of the middle cerebellar peduncle disrupt acquisition and retention of the rabbit's classically conditioned nictitating membrane response. Behavioral Neuroscience 1987;101:151-157. [PubMed: 3580118]

Logan, C. G. (1991). Cerebellar cortical involvement in excitatory and inhibitory classical conditioning. Doctoral Dissertation, Stanford University

Mamounas LA, Thompson RF, Madden J IV. Cerebellar GABAergic processes: Evidence for critical involvement in a form of simple associative learning in the rabbit. Proceedings of the National Academy of Science USA 1987;84:2101-2105.

Marchant HG, Mis FW, Moore JW. Conditioned inhibition of the rabbit's nictitating membrane response. Journal of Experimental Psychology 1972;95:408-411. [PubMed: 5071916]

Mauk MD. Roles of cerebellar cortex and nuclei in motor learning: Contradictions or clues? Neuron 1997;18:343-346. [PubMed: 9115728]

Mauk MD, Donegan NH. A model of Pavlovian eyelid conditioning based on the synaptic organization of the cerebellum. Learning and Memory 1997;4:130-158. [PubMed: 10456059]

Mauk MD, Garcia KS, Medina JF, Steele PM. Does cerebellar LTD mediate motor learning? Toward a resolution without a smoking gun. Neuron 1998;20:359-362. [PubMed: 9539112]

Mauk MD, Steinmetz JE, Thompson RF. Classical conditioning using stimulation of the inferior olive as the unconditioned stimulus. Proceeding of the National Academy of Science USA 1986;83:53495353.

McCormick DA, Guyer PE, Thompson RF. Superior cerebellar peduncle lesions selectively abolish the ipsilateral classically conditioned nictitating membrane/eyelid response of the rabbit. Brain Research 1982;244:347-350. [PubMed: 7116179]

McCormick DA, Steinmetz JE, Thompson RF. Lesions of the inferior olivary complex cause extinction of the classically conditioned eyeblink response. Brain Research 1985;359:120-130. [PubMed: 4075140]

McCormick DA, Thompson RF. Neuronal responses of the rabbit cerebellum during acquisition and performance of a classically conditioned nictitating membrane-eyelid response. Journal of Neuroscience 1984;11:2811-2822. [PubMed: 6502205]

McIntosh AR, Gonzalez-Lima F. Network analysis of functional auditory pathways mapped with fluorodeoxyglucose: Associative effects of a tone conditioned as a Pavlovian excitor or inhibitor. Brain Research 1993;627:129-140. [PubMed: 8293293]

McIntosh AR, Gonzalez-Lima F. Network interactions among limbic cortices, basal forebrain, and cerebellum differentiate a tone conditioned as a Pavlovian excitor of inhibitor: Fluorodeoxyglucose mapping and covariance structural modeling. Journal of Neurophysiology 1994;72:1717-1733. [PubMed: 7823097]

McIntosh AR, Gonzalez-Lima F. Functional network interactions between parallel auditory pathways during Pavlovian conditioned inhibition. Brain Research 1995;683:228-241. [PubMed: 7552359] 
Medina JF, Garcia KS, Nores WL, Taylor NM, Mauk MD. Timing mechanisms in the cerebellum: testing predictions of a large-scale computer simulation. Journal of Neuroscience 2000;20:5516-5525. [PubMed: 10884335]

Medina JF, Mauk MD. Computer simulation of cerebellar information processing. Nature Neuroscience 2000;3:1205-1211.

Mis FW. A midbrain-brainstem circuit for conditioned inhibition of the nictitating membrane response in the rabbit (Oryctolagus cuniculus). Journal of Comparative and Physiological Psychology 1977;91:975-988.

Moore JW, Choi JS. Conditioned response timing and integration in the cerebellum. Learning \& Memory 1997;4:116-129. [PubMed: 10456058]

Moore JW, Yeo CH, Oakley DA, Russell IS. Conditioned inhibition of the nictitating membrane response in decorticate rabbits. Behavioral Brain Research 1980;1:397-409.

Nicholson DA, Freeman JH Jr. Neuronal correlates of conditioned inhibition of the eyeblink response in the anterior interpositus nucleus. Behavioral Neuroscience 2002;116:22-36. [PubMed: 11895180]

Nores, W. L., Medina, J. F., Steele, P. M., \& Mauk, M. D. (2000). Relative contributions of cerebellar cortex and cerebellar nucleus to eyelid conditioning. In D. S. Woodruff-Pak, \& J. E. Steinmetz (Eds.), Eyeblink Classical Conditioning: Animal, (pp. 179-204). Amsterdam: Kluwer.

Pavlov, I. P. (1927). Conditioned reflexes London: Oxford University Press.

Paxinos. G. \& Watson, C. (1998). The rat brain in stereotaxic coordinates $\left(4^{\text {th }}\right.$ ed.). New York, NY: Academic Press.

Pearce JM, Hall G. A model for Pavlovian learning: variations in the effectiveness of conditioned but not unconditioned stimuli. Psychological Review 1980;87:523-552.

Racine RJ, Wilson DA, Gingell R, Sunderland D. Long-term potentiation in the interpositus and vestibular nuclei in the rat. Experimental Brain Research 1986;63:158-162.

Rescorla RA. Pavlovian conditioned inhibition. Psychological Bulletin 1969;72:77-94.

Rescorla, R. A., \& Wagner, A. R. (1972). A theory of Pavlovian conditioning: variations in the effectiveness of reinforcement and nonreinforcement. In A. H. Black \& W. F. Prokasy (Eds.), Classical Conditioning II: Current Research and Theory (pp. 64-99). New York: Appleton-CenturyCrofts.

Ribak CE, Peters A. An autoradiographic study of the projections from the lateral geniculate body of the rat. Brain Research 1975;92:341-368. [PubMed: 1174957]

Rosenfield ME, Moore JW. Red nucleus lesions disrupt the classically conditioned nictitating membrane response in rabbits. Behavioral Brain Research 1983;10:393-398.

Sakurai M. Synaptic modification of parallel fiber-Purkinje cell transmission in in vitro guinea-pig cerebellar slices. Journal of Physiology 1987;394:463-480. [PubMed: 2832595]

Salin PA, Malenka RC, Nicoll RA. Cyclic AMP mediates a presynaptic form of LTP at cerebellar parallel fiber synapses. Neuron 1996;16:797-803. [PubMed: 8607997]

Schreurs, B.G. (2000). Cellular correlates of eyeblink classical conditioning. In D.S. Woodruff-Pak, \& J.E. Steinmetz (Eds.), Eyeblink Classical Conditioning: Animal, (pp. 179-204). Amsterdam: Kluwer.

Schreurs BG, Gusev PA, Tomsic D, Alkon DL, Shi T. Intracellular correlates of acquisition and longterm memory of classical conditioning in Purkinje cell dendrites in slices of rabbit cerebellar lobule HVI. Journal of Neuroscience 1998;18:5498-5507. [PubMed: 9651230]

Schreurs BG, Oh MM, Alkon DL. Pairing-specific long-term depression of Purkinje cell excitatory postsynaptic potentials results from a classical conditioning procedure in the rabbit cerebellar slice. Journal of Neurophysiology 1996;75:1051-1060. [PubMed: 8867117]

Schreurs BG, Sanchez-Andres JV, Alkon DL. Learning-specific differences in Purkinje-cell dendrites of lobule HVI (lobulus simplex): intracellular recording in a rabbit cerebellar slice. Brain Research 1991;548:18-22. [PubMed: 1868333]

Schreurs BG, Tomsic D, Gusev PA, Alkon DL. Dendritic excitability microzones and occluded longterm depression after classical conditioning of the rabbit's nictitating membrane response. Journal of Neurophysiology 1997;77:86-92. [PubMed: 9120599] 
Solomon PR. Role of the hippocampus in blocking and conditioned inhibition of the rabbit's nictitating membrane response. Journal of Comparative and Physiological Psychology 1977;91:407-417. [PubMed: 404342]

Solomon PR, Lewis JL, LoTurco JJ, Steinmetz JE, Thompson RF. The role of the middle cerebellar peduncle in acquisition and retention of the rabbit's classically conditioned nictitating membrane response. Bulletin of the Psychonomic Society 1986;24:75-78.

Steinmetz JE. Neuronal activity in the rabbit interpositus nucleus during classical NM-conditiong with a pontine-nucleus-stimulation CS. Psychological Science 1990;1:378-382.

Steinmetz JE, Lavond DG, Ivkovich D, Logan CG, Thompson RF. Disruption of classical eyelid conditioning after cerebellar lesions: Damage to a memory trace system or simple performance deficit? Journal of Neuroscience 1992;12:4403-4426. [PubMed: 1432102]

Steinmetz JE, Lavond DG, Thompson RF. Classical conditioning of the rabbit eyelid response with mossy fiber stimulation as the conditioned stimulus. Bulletin of the Psychonomic Society 1985;23:245-248.

Steinmetz JE, Lavond DG, Thompson RF. Classical conditioning in rabbits using pontine nucleus stimulation as a conditioned stimulus and inferior olive stimulation as an unconditioned stimulus. Synapse 1989;3:225-233. [PubMed: 2718098]

Steinmetz JE, Logan CG, Rosen DJ, Thompson JK, Lavond DG, Thompson RF. Initial localization of the acoustic conditioned stimulus projection system to the cerebellum essential for classical eyelid conditioning. Proceeding of the National Academy of Science USA 1987;84:3531-3535.

Steinmetz JE, Rosen DJ, Chapman PF, Lavond DG, Thompson RF. Classical conditioning of the rabbit eyelid response with a mossy fiber stimulation CS. I. Pontine nuclei and middle cerebellar peduncle stimulation. Behavioral Neuroscience 1986;100:878-887. [PubMed: 3814342]

Takada M, Itoh K, Yasui Y, Mitani A, Nomura S, Mizuno N. Distribution of premotor neurons for orbicularis oculi motoneurons in the cat, with particular reference to possible pathways for blink reflex. Neuroscience Letters 1984;50:251-255. [PubMed: 6493629]

Thompson, R. F. (2000). Discovering the brain substrates of eyeblink classical conditiong. In D. S. Woodruff-Pak, \& J. E. Steinmetz (Eds.), Eyeblink Classical conditioning: Animal (pp. 17-49). Amsterdam: Kluwer.

Thompson RF, Krupa DJ. Organization of memory traces in the mammalian brain. Annual Review of Neuroscience 1994;17:519-549.

Tracy JA, Thompson JK, Krupa DJ, Thompson RF. Evidence of plasticity in the pontocerebellar conditioned stimulus pathway during classical conditioning of the eyeblink response in the rabbit. Behavioral Neuroscience 1998;112:267-285. [PubMed: 9588477]

Waddell, J., Pistell, P. J., Heldt, S. A., \& Falls, W. A. (2000). The effect of lesions of the superior colliculus of the elicitation and reduction of fear-potentiated startle. Society for Neuroscience Abstracts.

Wells GR, Hardiman MJ, Yeo CH. Visual projections to the pontine nuclei in the rabbit: orthograde and retrograde tracing studies with WGA-HRP. Journal of Comparative Neurology 1989;279:629-652. [PubMed: 2465324]

Yeo CH, Hardiman MJ, Glickstein M. Classically conditioning of the nictitating membrane response of the rabbit. IV. Lesions of the inferior olive. Experimental Brain research 1986;63:81-92.

Yeo CH, Hardiman MJ, Moore JW, Russell IS. Retention of conditioned inhibition of the nictitating membrane response in decorticate rabbits. Behavioral Brain Research 1983;10:383-392.

Yeo CH, Hesslow G. Cerebellum and conditioned reflexes. Trends in Cognitive Sciences 1998;2:322330. 


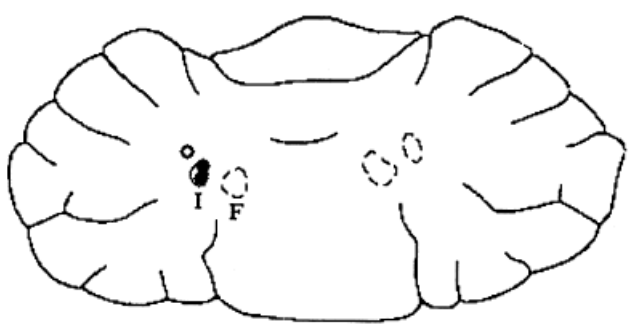

$-5.3 \mathrm{~mm}$

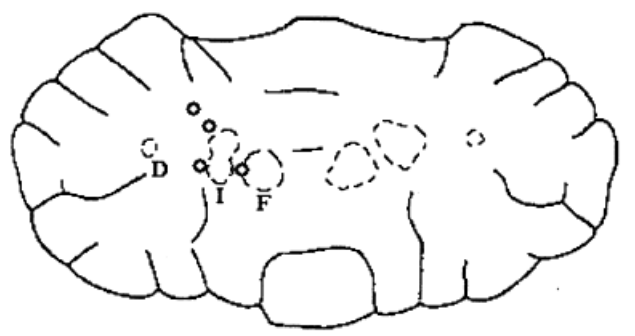

\section{$-5.6 \mathrm{~mm}$}

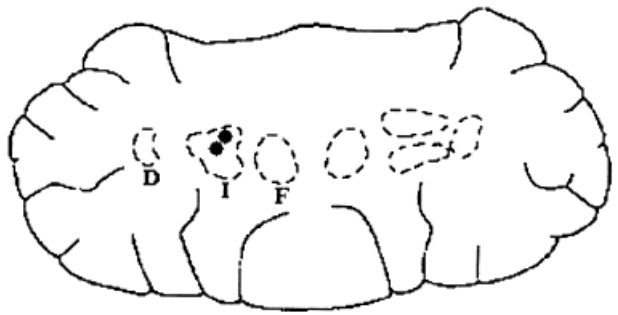

$-5.8 \mathrm{~mm}$

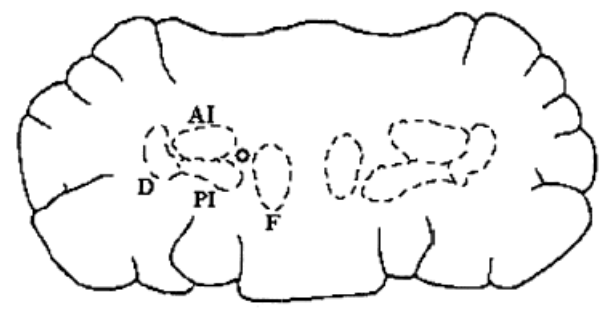

$-6.1 \mathrm{~mm}$

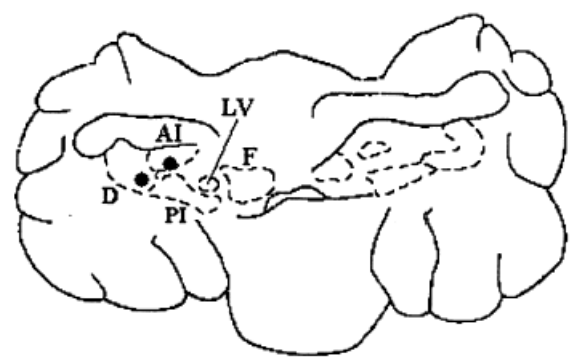

\section{$-6.4 \mathrm{~mm}$}

Fig. 1.

Drawings of representative horizontal cerebellar sections showing the placement of cannula tips. Open circles represent misses and filled circles represent hits. Dorsal-ventral placement is indicated in number of millimeters below bregma. Abbreviations: D (dentate nucleus), I (interpositus nucleus), AI (anterior interpositus), PI (posterior interpositus), F (fastigial nucleus), LV (lateral vestibular nucleus). The anterior of the two hits is in the top section was slightly dorsal to -5.3 . This figure was modified from drawings in the stereotaxic atlas of Paxinos and Watson (1998). 


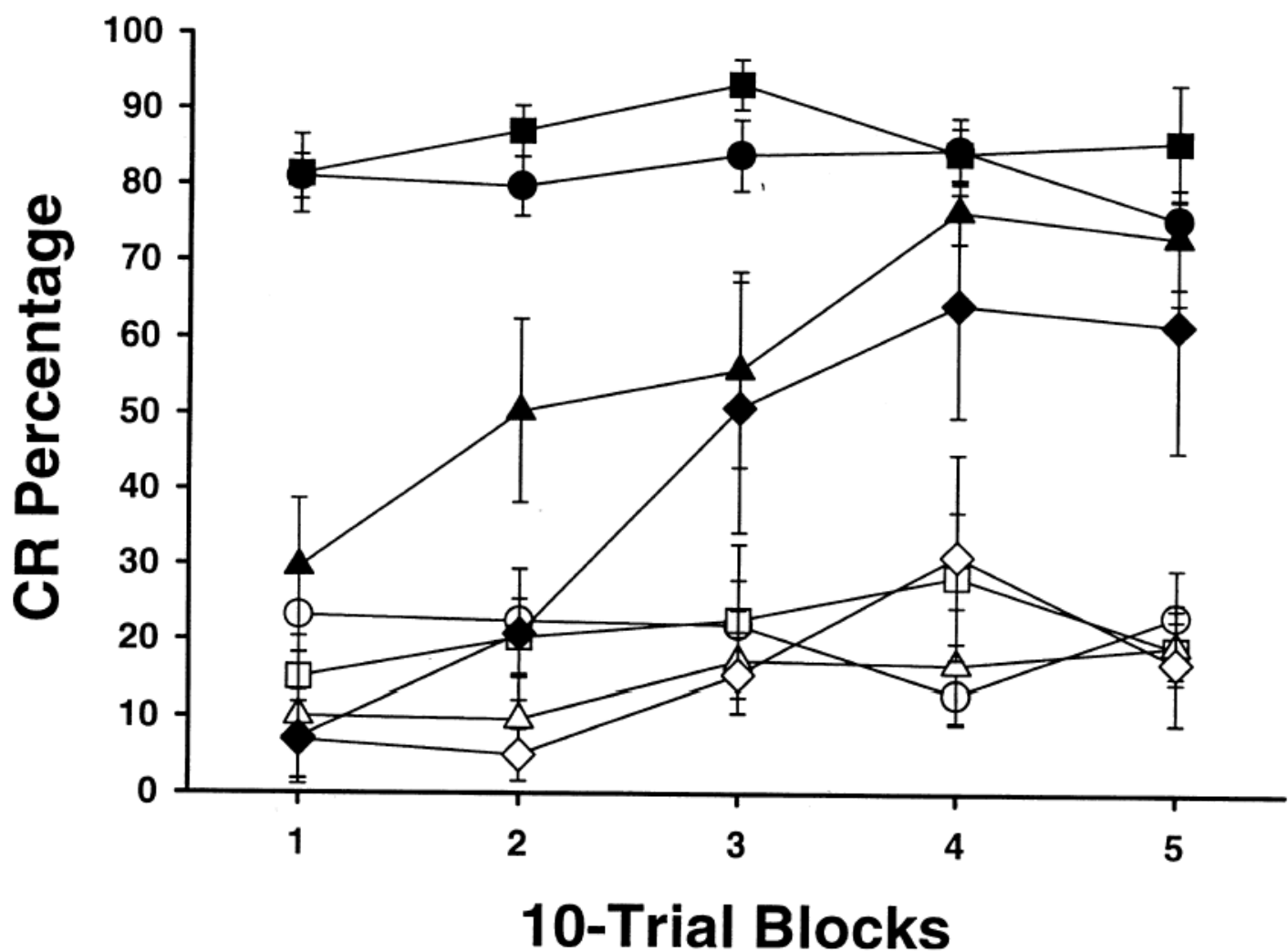

Fig. 2.

Mean $( \pm$ SEM) CR percentage for rats with cannula hits on the interpositus or dentate nucleus during feature-negative discrimination training across doses of picrotoxin. Sessions were divided into 5 blocks of 10 tone-shock trials $(\mathrm{T}+)$ and 10 tone-light trials (TL-). Filled symbols represent $\mathrm{T}+$ trials and open symbols represent $\mathrm{TL}-$ trials. The vehicle used was artificial cerebro-spinal fluid (ACSF). The doses were ACSF alone (circles), $1.0 \mathrm{mM}$ picrotoxin (squares), $2.0 \mathrm{mM}$ picrotoxin (triangles), and $4.0 \mathrm{mM}$ picrotoxin (diamonds). All doses were $0.5 \mu \mathrm{l}$ in volume. 


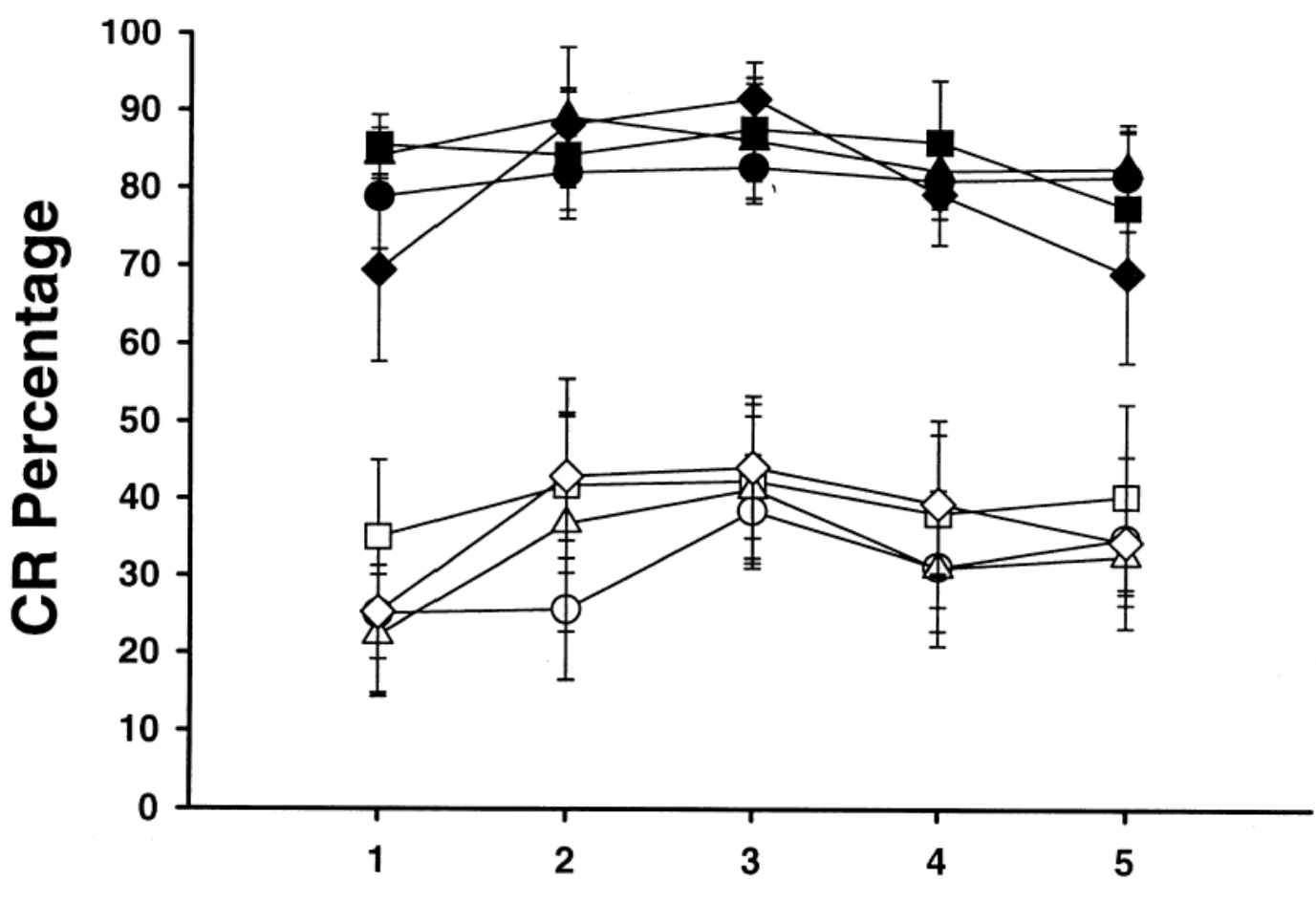

10-Trial Blocks

Fig. 3.

Mean $( \pm$ SEM) CR percentage for rats with cannula misses during feature-negative discrimination training across doses of picrotoxin. Sessions were divided into 5 blocks of 10 tone-shock trials $(\mathrm{T}+)$ and 10 tone-light trials $(\mathrm{TL}-)$. Filled symbols represent $\mathrm{T}+$ trials and open symbols represent TL-trials. The vehicle used was artificial cerebro-spinal fluid (ACSF). The doses were ACSF alone (circles), $1.0 \mathrm{mM}$ picrotoxin (squares), $2.0 \mathrm{mM}$ picrotoxin (triangles), $4.0 \mathrm{mM}$ picrotoxin (diamonds). All doses were $0.5 \mu \mathrm{l}$ in volume. 


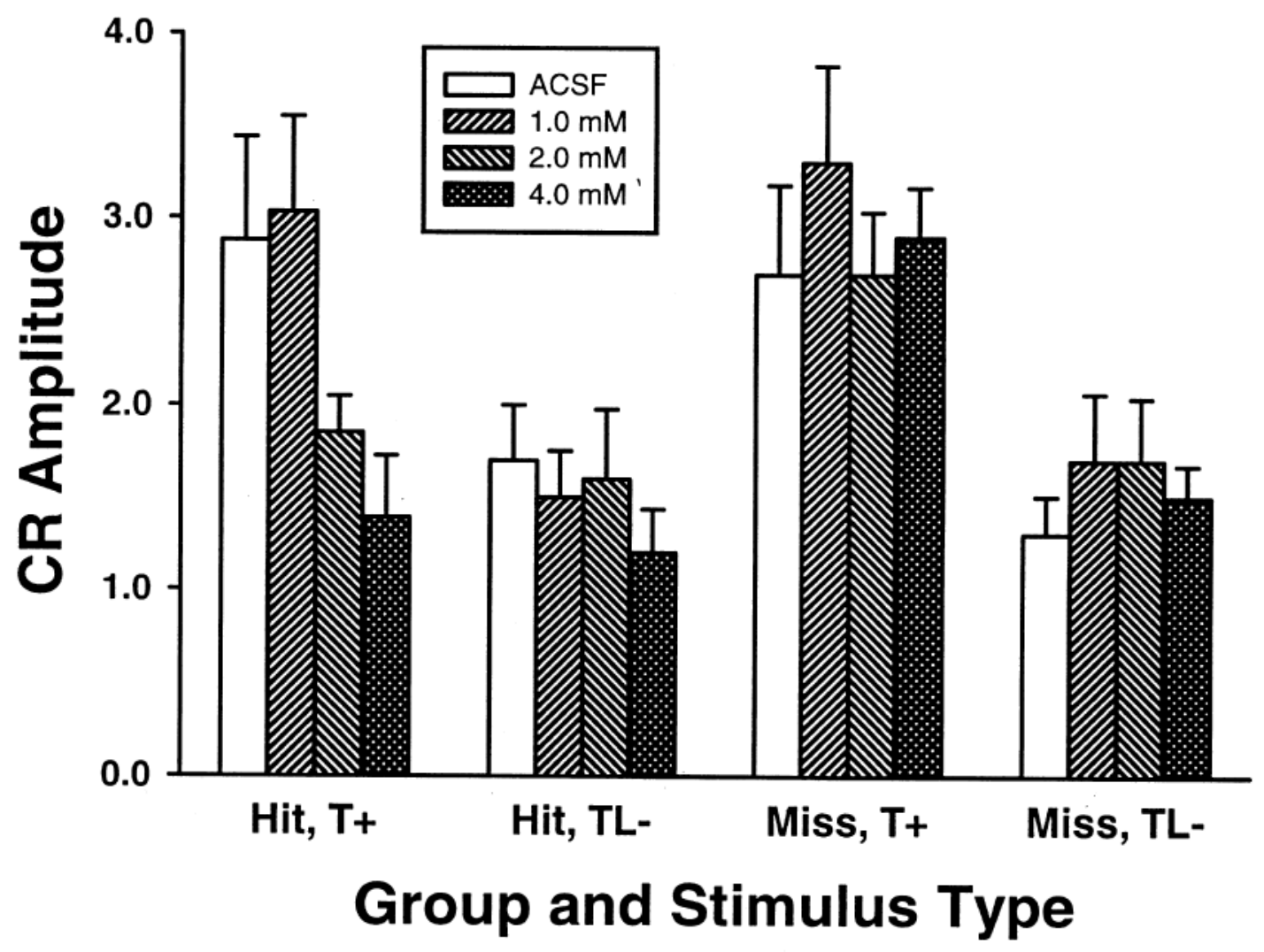

Fig. 4.

Mean (+ SEM) CR amplitude for both cannula hit (left two sets of bars) and miss (right two sets of bars) groups. CR amplitudes are shown by trial type across doses of picrotoxin and ACSF. Tone-shock trials ( $\mathrm{T}+$, left) and tone-light-no shock trials $(\mathrm{TL}-$, right) are displayed separately for each group. Shading indicates ACSF or dose of picrotoxin (from left to right: ACSF, $1.0 \mathrm{mM}, 2.0 \mathrm{mM}, 4.0 \mathrm{mM}$ ). 


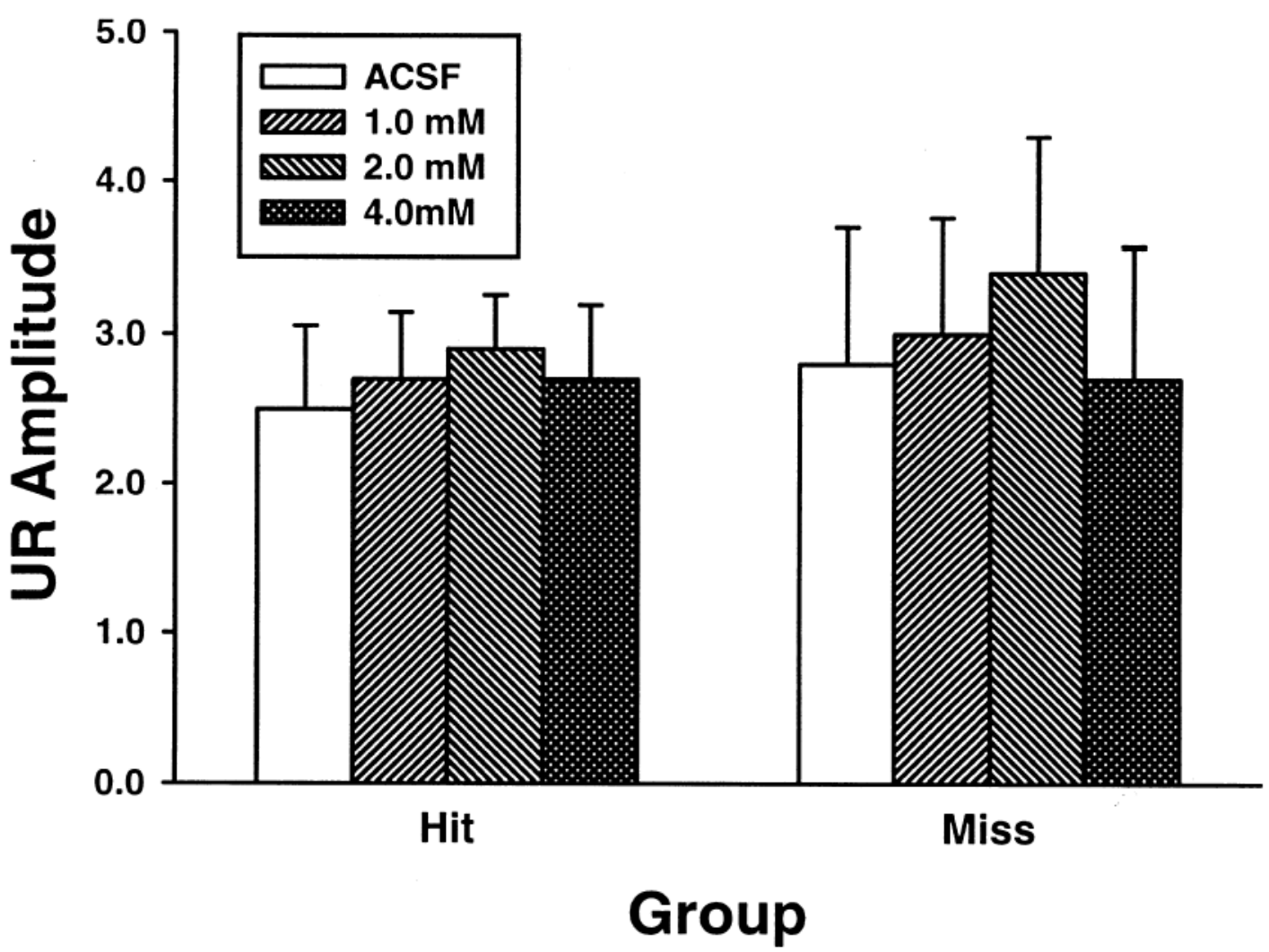

Fig. 5.

Mean (+ SEM) UR amplitude for both cannula hit (left) and miss (right) groups. UR amplitudes are shown across doses of picrotoxin and ACSF during tone-shock $(\mathrm{T}+)$ trials. Shading indicates ACSF or dose of picrotoxin (from left to right: ACSF, $1.0 \mathrm{mM}, 2.0 \mathrm{mM}, 4.0 \mathrm{mM}$ ). 
Summation

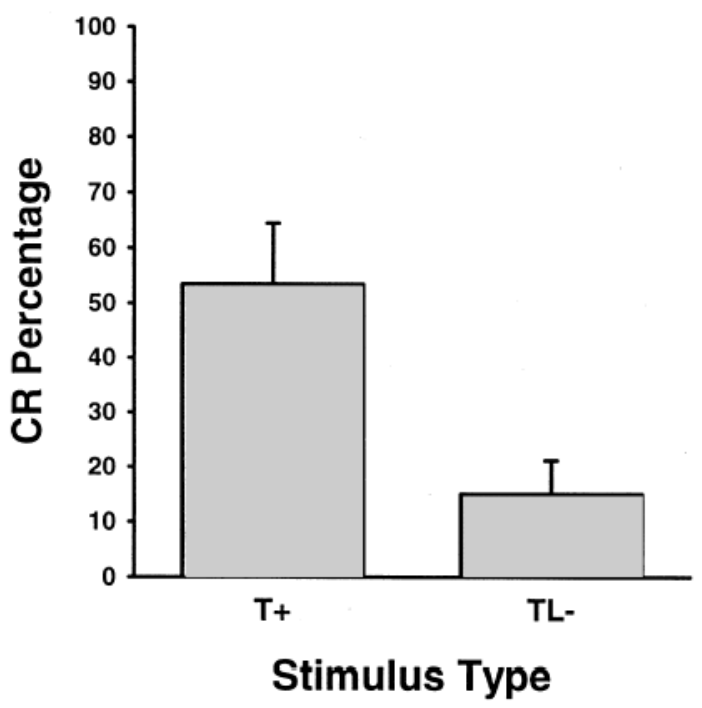

\section{Retardation}

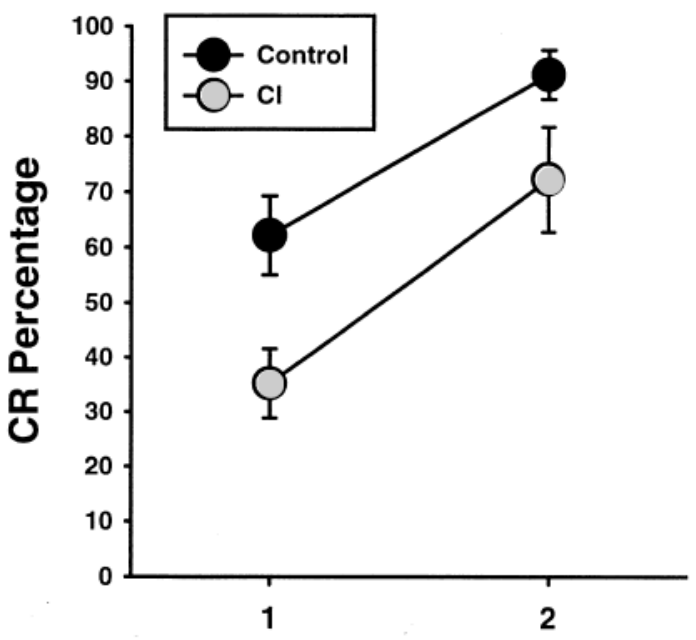

100-Trial Sessions

Fig. 6.

Mean ( \pm SEM) CR percentage during the summation (left) and retardation (right) tests. CR percentage during the retardation test was compared to a control group from a previous study across two 100-trial sessions. 
TABLE 1

Training procedure (symbol designations: $+=$ shock US, $-=$ no US, $\mathrm{T}_{1}=8 \mathrm{kHz}$ tone, $\mathrm{T}_{2}=2 \mathrm{kHz}$ tone, and $\mathrm{L}=$ light)

\begin{tabular}{llll}
\hline Phase & \multicolumn{1}{c}{ Name } & Stimuli \\
\hline 1 & Acquisition & $\mathrm{T}_{1}+$ & Drug \\
2 & Feature-negative discrimination & $\mathrm{T}_{2}+, \mathrm{T}_{2} \mathrm{~L}-$ & none \\
3 & Drug infusion/retention test & $\mathrm{T}_{2}+, \mathrm{T}_{2} \mathrm{~L}-$ & none \\
4 & Summation test & $\mathrm{T}_{1}-, \mathrm{T}_{1} \mathrm{~L}-$ & none \\
5 & Retardation test & $\mathrm{L}+$ & none \\
& & & \\
\hline
\end{tabular}

